\title{
Organic Phase Cyclopentadienylnickelthiolate Sensor System for Electrochemical Determination of Sulfur Dioxide
}

\author{
Aoife Morrin, ${ }^{\mathrm{a}, \mathrm{b}}$ Richard M. Moutloali, ${ }^{\mathrm{a}}$ Anthony J. Killard, ${ }^{\mathrm{b}}$ Malcolm R. Smyth, ${ }^{\mathrm{b}}$ James Darkwa, ${ }^{\text {a }}$ Emmanuel I. Iwuoha*a \\ a University of the Western Cape, Department of Chemistry, Bellville 7535, South Africa \\ *e-mail: jdarkwa@uwc.ac.za; eiwuoha@uwc.ac.za \\ b Dublin City University, School of Chemical Sciences, Dublin 9, Ireland
}

Received: January 8, 2004

Final version: Feruary 11, 2004

\begin{abstract}
A series of cyclopentadienylnickelthiolate complexes, [Ni $\left.\left(\mathrm{PBu}_{3}\right)\left(\eta^{5}-\mathrm{C}_{5} \mathrm{H}_{5}\right)\left(\mathrm{SC}_{6} \mathrm{H}_{4} \mathrm{X}-4\right)\right]\left(\mathrm{X}=\mathrm{F}, \mathrm{Cl}, \mathrm{Br}, \mathrm{NH}_{2}\right)$, were shown to express stable reversible electrochemical properties even after formation of $\mathrm{SO}_{2}$ adducts in organic phase consisting of argon purged $\mathrm{CH}_{2} \mathrm{Cl}_{2} / 0.1 \mathrm{M}\left[n-\mathrm{Bu}_{4} \mathrm{~N}\right]\left[\mathrm{BF}_{4}\right]$. The formal potentials $\left(E^{\circ \prime}\right)$ values of the compounds ranged from 265 to $431 \mathrm{mV} / \mathrm{Ag}-\mathrm{AgCl}$ depending on the para substituent of the benzene thiolate ligand. Electrochemical, UVvis and ${ }^{1} \mathrm{H}$ NMR spectroscopic analyses show that the formation of $\mathrm{SO}_{2}$ adducts causes the perturbation of the electronic density of the nickel metal center, indicated by shifts in the $E^{\circ \prime}$ values of the $\mathrm{Ni}^{\mathrm{II} / \mathrm{III}}$ redox couple that is dependent on $\mathrm{SO}_{2}$ concentration. The detection limits of the resulting organic phase electrochemical gas sensor

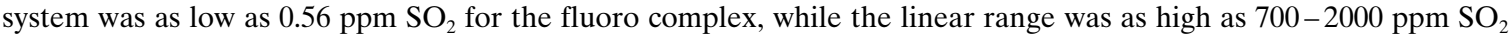
for the amino complex.
\end{abstract}

Keywords: Sulfur dioxide determination, Electrochemical sulfur dioxide sensor, Organic phase sulfur dioxide sensor, Cyclopentadienylnickelthiolate complex, Potentiometric $\mathrm{SO}_{2}$ sensor

\section{Introduction}

Environmental and health hazards associated with sulfur dioxide pollution mandate stringent monitoring of atmospheric sulfur dioxide in many countries [1]. A number of instrumental methods are available to monitor $\mathrm{SO}_{2}$ levels in the environment. These include ultraviolet fluorescence [2], flame photometry [3] and ion chromatography [4,5]. These instrumental techniques require sample treatment steps that provide additional scope for error. Conductometric gas sensors have also been used for $\mathrm{SO}_{2}$ detection [5-7]. However, most conductometric gas sensors rely on alterations (or modulation) in the electronic conductivity of the sensing layer, or change in the ionic conductivity of the electrolyte by interaction with the analyte.

Another $\mathrm{SO}_{2}$ detection method that has been reported [8] is the use of electrochemical (or amperometric) gas sensor, which measures the current associated with electro-oxidation/reduction of the gas. In aqueous media, the oxidation of $\mathrm{SO}_{2}$ at modified electrode results in the formation of sulfate ions through sulfite and bisulfite intermediates. This reaction is sluggish and requires high overpotential $[9,10]$. In non-aqueous media, $\mathrm{SO}_{2}$ is reduced to dithionate through a free-radical $\left(\mathrm{SO}_{2}^{-}\right)$intermediate [11].

In this study we present an electrochemical method for the determination of $\mathrm{SO}_{2}$ that does not involve $\mathrm{SO}_{3}{ }^{2-}, \mathrm{HSO}_{3}{ }^{2-}$, and $\mathrm{SO}_{2}{ }^{-}$intermediates. This method involves the complexation of $\mathrm{SO}_{2}$ with electroactive metal thiolates, such as cyclopentadienylnickel thiolates, followed by the determination of the change in formal potential associated with the binding of $\mathrm{SO}_{2}$. Complex formation between metal thiolates and $\mathrm{SO}_{2}$ is very well documented [12-17]. The $\mathrm{SO}_{2}$ adducts of the metal thiolate complex contain a generally weak sulfur-sulfur bond between the thiolate and $\mathrm{SO}_{2}$ sulfur atoms which ensures reversible absorption of $\mathrm{SO}_{2}$. One question that is yet to be answered is whether the $\mathrm{SO}_{2}$ adducts are electroactive and stable enough for $\mathrm{SO}_{2}$ determination. This paper contains preliminary studies of some cyclopentadienylnickelthiolates screened for application as organic phase electrochemical sensors for $\mathrm{SO}_{2}$ that answers the above question. In order to assess the ability of cyclopentadienylnickelthiolates as electrochemical sensor systems for sulfur dioxide, two types of thiolato complexes (Scheme 1) were investigated. Cyclic and square wave voltammetry experiments were performed with each type of the nickel thiolate complexes before and after reaction with sulfur dioxide.

\section{Experimental}

All preparations were carried out in reagent grade solvents. Dichloromethane used for electrochemical experiments was refluxed twice over $\mathrm{P}_{2} \mathrm{O}_{5}$ for $24 \mathrm{~h}$, distilled under nitrogen and stored over activated molecular sieves. Complexes $\left[\mathrm{Ni}\left(\mathrm{PBu}_{3}\right)\left(\eta^{5}-\mathrm{C}_{5} \mathrm{H}_{5}\right)\left(\mathrm{SC}_{6} \mathrm{H}_{4} \mathrm{X}-4\right)\right]\left(\mathrm{X}=\mathrm{F}, \mathrm{Cl}, \mathrm{Br}, \mathrm{NH}_{2}\right)$ $[16,18]$ and $\left[\mathrm{Ni}\left(\mathrm{PBu}_{3}\right)\left(\eta^{5}-\mathrm{C}_{5} \mathrm{H}_{5}\right)\left(\mathrm{SC}_{6} \mathrm{H}_{4} \mathrm{NC}(\mathrm{H}) \mathrm{C}_{6} \mathrm{H}_{4} \mathrm{X}-4\right)\right]$ $(\mathrm{X}=\mathrm{F}, \mathrm{Me}, \mathrm{OMe})[19-22]$, were prepared as previously reported. All reactions were performed under a nitrogen atmosphere, but the air and moisture stable complexes that were formed were worked-up in air. 


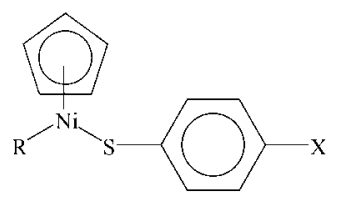

Type 1: $\mathrm{R}=\mathrm{Bu}_{3} \mathrm{P}, \mathrm{X}=\mathrm{NII}_{2}, \mathrm{~F}, \mathrm{Cl}, \mathrm{Br}$

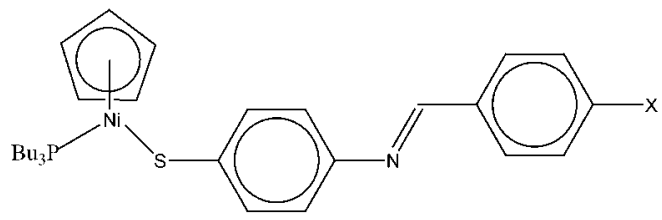

Type 2: $\mathrm{X}=\mathrm{F}, \mathrm{Me}, \mathrm{OMe}$

Scheme 1. Structures of complexes screened as $\mathrm{SO}_{2}$ sensors materials.

${ }^{1} \mathrm{H}$ NMR spectra were run on a Varian Gemini 2000 spectrometer at $200 \mathrm{MHz}$ and referenced internally to residual $\mathrm{CDCl}_{3}$ at $7.26 \mathrm{ppm}$. Elemental analyses were carried out with a CARLO EBER CHN analyzer. The electrochemical measurements were performed with a BAS $50 \mathrm{~W}$ potentiostat. A conventional three-electrode cell system which was used consisted of a glassy carbon working electrode (1 mm diameter), $\mathrm{Ag} / \mathrm{AgCl}$ reference electrode and a platinum wire auxiliary electrode. Prior to use, the glassy carbon electrodes were cleaned by successive polishing on aqueous slurries of $1 \mu \mathrm{m}, 0.3 \mu \mathrm{m}$ and $0.05 \mu \mathrm{m}$ alumina powder, followed by thorough rinsing with deionised water and acetone. The experiments were carried out at room temperature under an argon atmosphere in an organic phase consisting of degassed dichloromethane containing $0.1 \mathrm{M}$ tetrabutylammonium tetrafluoroborate $\left[n-\mathrm{Bu}_{4} \mathrm{~N}\right]\left[\mathrm{BF}_{4}\right]$ as supporting electrolyte. A $2 \mathrm{mM}$ solution of cyclopentadienylnickelthiolate complex was used in all electrochemical determinations. Cyclic voltammetry experiments were carried out at a scan rate of $50 \mathrm{mV} \mathrm{s}^{-1}$, under diffusion-limiting conditions. After performing the initial run under argon the working electrode was removed and polished, prior to the bubbling of $\mathrm{SO}_{2}$ through the solution for 2 minutes. The voltammetry experiment was immediately repeated on the $\mathrm{SO}_{2}$ saturated solution under the same conditions.

\section{Results and Discussion}

\subsection{Type 1 Electrochemical $\mathrm{SO}_{2}$ Sensors: $\left[\mathrm{Ni}\left(\mathrm{PBu}_{3}\right)\left(\eta^{5}-\mathrm{C}_{5}\right.\right.$ $\left.\left.\mathrm{H}_{5}\right)\left(\mathrm{SC}_{6} \mathrm{H}_{4} \mathrm{X}-4\right)\right]$}

The formation of $\mathrm{SO}_{2}$ adduct of the Type 1 complexes, $\left[\mathrm{Ni}\left(\mathrm{PBu}_{3}\right)\left(\eta^{5}-\mathrm{C}_{5} \mathrm{H}_{5}\right)\left(\mathrm{SC}_{6} \mathrm{H}_{4} \mathrm{X}-4\right)\right]\left(\mathrm{X}=\mathrm{F}, \mathrm{Cl}, \mathrm{Br}, \mathrm{NH}_{2}\right)$, in the organic phase reaction medium was confirmed by ${ }^{1} \mathrm{H}$ NMR and UV-vis spectroscopy. All the Type 1 complexes formed stable $\mathrm{SO}_{2}$ adducts in solution, initially observed by a distinct color change from a dark brown to a reddish color after bubbling excess $\mathrm{SO}_{2}$ through the solutions. ${ }^{1} \mathrm{H}$ NMR spectrum showed that the cyclopentadienyl singlet attached to the $\mathrm{Ni}$ (II) center for $\mathrm{PBu}_{3}$ ligand complexes, was observed at $5.15 \mathrm{ppm}$ in the original spectrum, but shifted downfield to a value of $5.53 \mathrm{ppm}$, upon exposure to $\mathrm{SO}_{2}$. This was a deshielding effect as a result of a decrease in electron density around the nickel center.

Typical UV-vis spectra are shown in Figure 1 for $[\mathrm{Ni}(\mathrm{P}-$ $\left.\left.\mathrm{Bu}_{3}\right)\left(\eta^{5}-\mathrm{C}_{5} \mathrm{H}_{5}\right)\left(\mathrm{SC}_{6} \mathrm{H}_{4} \mathrm{NH}_{2-} 4\right)\right]$. The UV-vis spectra show increases in absorption and shifts in absorption wavelength on the formation of $\mathrm{SO}_{2}$ adduct of the complex. In the UV region (Fig. 1a), the absorption peaks of the complex at 260 and $320 \mathrm{~nm}$ were replaced by a large peak at $290 \mathrm{~nm}\left(\mathrm{~A}_{(290}\right.$ $\mathrm{nm}) \approx 2 \mathrm{~A}_{(260 \mathrm{~nm})}$ and $\left.4.5 \mathrm{~A}_{(320 \mathrm{~nm})}\right)$ after $\mathrm{SO}_{2}$ adduct formation. These transitions in the UV region are ligand-based and indicate the attachment of $\mathrm{SO}_{2}$ to a site on the ligand. In the visible region (Fig. 1b), the $\mathrm{d}-\mathrm{d}$ transition of the Ni center in the complex occurs at about $400 \mathrm{~nm}$. The wavelength of this transition shifts only slightly to about $390 \mathrm{~nm}\left(\mathrm{~A}_{(390 \mathrm{~nm})} \approx\right.$ $\left.3 \mathrm{~A}_{(400 \mathrm{~nm})}\right)$ after adduct formation, indicating that it is most likely the $\mathrm{SO}_{2}$ is not directly bonded to the metal and the electronic state of the metal is only affected secondarily.

Figure 2 shows typical voltammograms observed for Type 1 complexes in $\mathrm{CH}_{2} \mathrm{Cl}_{2}$ solvent medium containing $0.1 \mathrm{M}[n$ $\left.\mathrm{Bu}_{4} \mathrm{~N}\right]\left[\mathrm{BF}_{4}\right]$ as electrolyte. Type 1 series of compounds exhibited quasi-reversible redox behavior before and after the formation of sulfur dioxide adducts. As shown in the data in Table 1, the ratio of the cyclic voltammetric anodic to cathodic peak currents $\left(I_{\mathrm{p}, \mathrm{a}} / I_{\mathrm{p}, \mathrm{c}}\right)$ was approximately unity in both the thiolate complexes and their sulfur dioxide adducts. The peak separation $\Delta E_{\mathrm{p}}\left(\Delta E_{\mathrm{p}}=E_{\mathrm{p}, \mathrm{a}}-E_{\mathrm{p}, \mathrm{c}}\right)$ values ranged from $57 \mathrm{mV}$ for $\left[\mathrm{Ni}\left(\mathrm{PBu}_{3}\right)\left(\eta^{5}-\mathrm{C}_{5} \mathrm{H}_{5}\right)\left(\mathrm{SC}_{6} \mathrm{H}_{4} \mathrm{~F}-4\right)\right]$ to $119 \mathrm{mV}$ for $\left[\mathrm{Ni}\left(\mathrm{PBu}_{3}\right)\left(\eta^{5}-\mathrm{C}_{5} \mathrm{H}_{5}\right)\left(\mathrm{SC}_{6} \mathrm{H}_{4} \mathrm{Cl}-4\right)\right]$, as would be expected for quasi-reversible diffusion controlled electrochemical processes. However, within limits of experimental error, the $\Delta E_{\mathrm{p}}$ values for each compound remained essentially the same before and after $\mathrm{SO}_{2}$ adduct formation. This shows that the Faradaic process being observed in both $\mathrm{SO}_{2}$-free and $\mathrm{SO}_{2}$-containing compound is the same, namely the diffusion-controlled $\mathrm{Ni}^{\mathrm{II} / \mathrm{III}}$ electrochemistry of the $[\mathrm{Ni}(\mathrm{P}-$ $\left.\left.\mathrm{Bu}_{3}\right)\left(\eta^{5}-\mathrm{C}_{5} \mathrm{H}_{5}\right)\left(\mathrm{SC}_{6} \mathrm{H}_{4} \mathrm{X}-4\right)\right]\left(\mathrm{X}=\mathrm{F}, \mathrm{Cl}, \mathrm{Br}, \mathrm{NH}_{2}\right)$. The standard rate constant $\left(k^{\circ}\right)$ value of a typical $\mathrm{SO}_{2}$-adduct $(\mathrm{X}=$

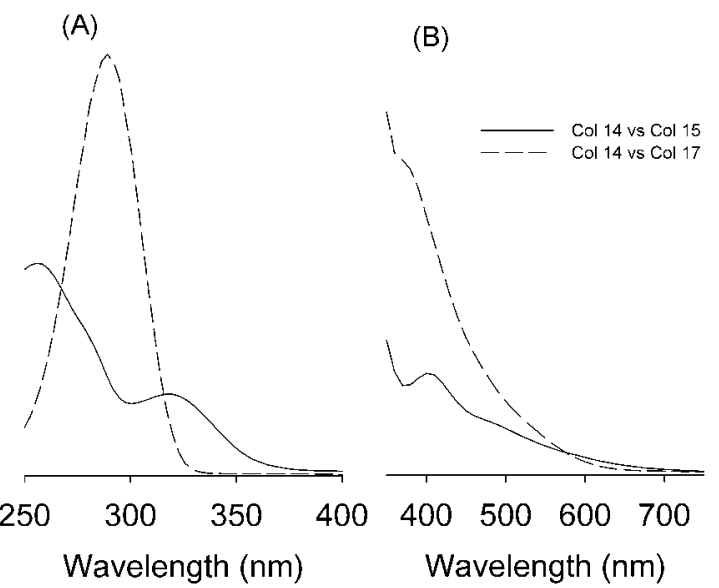

Fig. 1. UV-vis spectra for $\left[\mathrm{Ni}\left(\mathrm{PBu}_{3}\right)\left(\eta^{5}-\mathrm{C}_{5} \mathrm{H}_{5}\right)\left(\mathrm{SC}_{6} \mathrm{H}_{4} \mathrm{NH}_{2}-4\right)\right]$. A) UV region showing the ligand-based transitions. $\mathrm{B}$ ) Visible region showing the metal-based transition. 
$\mathrm{NH}_{2}$ ) calculated by the analysis of the Tafel region of the cyclic voltammogram is $2.54 \times 10^{-9} \mathrm{~cm} \mathrm{~s}^{-1}$. This low $k^{\circ}$ value is in agreement with what has been reported for electron transfer reaction at the electrode that is coupled to other chemical and physical processes [23]. In the present study the reversible binding of $\mathrm{SO}_{2}$ is coupled to $\left[\mathrm{Ni}\left(\mathrm{PBu}_{3}\right)\left(\eta^{5}-\mathrm{C}_{5}\right.\right.$ $\left.\left.\mathrm{H}_{5}\right)\left(\mathrm{SC}_{6} \mathrm{H}_{4} \mathrm{NH}_{2}-4\right)\right]$ electrochemistry.

As shown in Table 1, the formal potentials of the $\mathrm{SO}_{2}$ adducts were generally higher than for the thiolate complexes by up to $60 \mathrm{mV} / \mathrm{Ag}-\mathrm{AgCl}$ for the case of $[\mathrm{Ni}$ $\left.\left(\mathrm{PBu}_{3}\right)\left(\eta^{5}-\mathrm{C}_{5} \mathrm{H}_{5}\right)\left(\mathrm{SC}_{6} \mathrm{H}_{4} \mathrm{NH}_{2}-4\right)\right]$, which is indicative of the perturbation of the redox properties of the thiolate complex by the binding of $\mathrm{SO}_{2}$. The magnitude of formal potential shift $\left(E^{\circ}{ }_{\text {shift }}\right)$ varied with the substituent on the thiolate ligand. The $\mathrm{NH}_{2}\left(E^{\circ \prime}\right.$ shift $\left.=57 \mathrm{mV}\right)$ and $\mathrm{F}\left(E^{\circ \prime}{ }_{\text {shift }}=60 \mathrm{mV}\right)$ substituents exhibited the largest shift in formal potential after $\mathrm{SO}_{2}$ binding. The data suggests a relationship between the electron withdrawing ability of the substituent and the formal potential of the complex. This was verified by the analysis of the Hammett constants of the substituents. Figure 3 shows that the $E^{\circ \prime}$ value of the Type 1 compounds

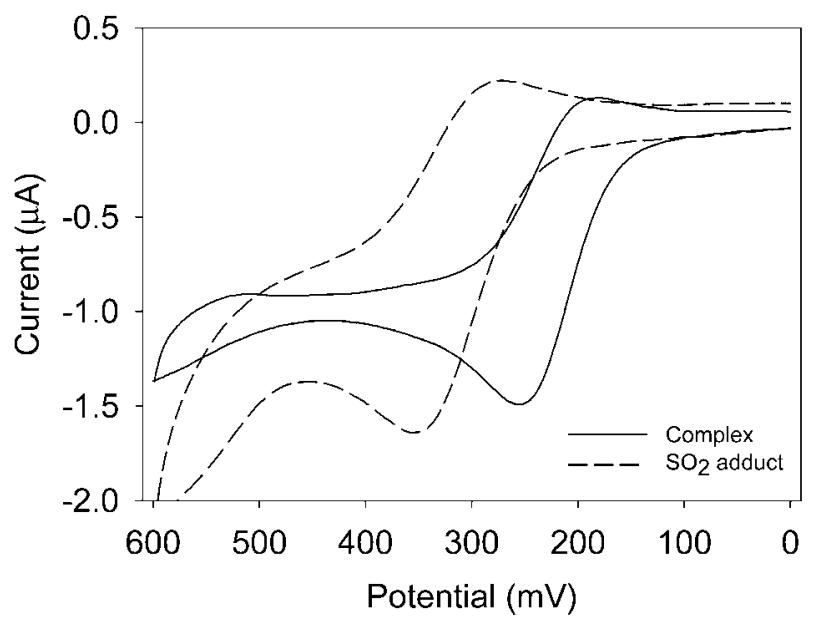

Fig. 2. Cyclic voltammograms for the complex $\left[\mathrm{Ni}\left(\mathrm{PBu}_{3}\right)-\right.$ $\left.\left(\eta-\mathrm{C}_{5} \mathrm{H}_{5}\right)\left(\mathrm{SC}_{6} \mathrm{H}_{4} \mathrm{NH}_{2}-4\right)\right]$ and its $\mathrm{SO}_{2}$ adduct. varied in accordance with the value of the Hammett constant $\left(\sigma_{\mathrm{p}}\right)$ of the substituent in the para-position of the thiolate ligand. The formal potentials of the $\mathrm{SO}_{2}$ adduct increase in the order $\mathrm{Br} \cong \mathrm{Cl}>\mathrm{F}>\mathrm{NH}_{2}$. It is important to emphasis that $\mathrm{Br}$ and $\mathrm{Cl}$ substituents which have the same $\sigma_{\mathrm{p}}$ value of 0.23 , show remarkable similarity in their $E^{\circ \prime}$ values for the $\mathrm{SO}_{2}$ adducts $\left(E_{\mathrm{Br}}^{\circ \prime}=413 \mathrm{mV}\right.$ and $\left.E^{\circ \prime}{ }_{\mathrm{Cl}}=412 \mathrm{mV}\right)$ even though the formal potentials of their $\mathrm{SO}_{2}$-free analogues differ by up to $47 \mathrm{mV}$. This behavior of $\mathrm{Br}$ - and $\mathrm{Cl}-$ substituted $\mathrm{SO}_{2}$ adducts confirms the observed linear relationship between $\sigma_{\mathrm{p}}$ and $E^{\circ \prime}$ as shown in Figure 3. It has been proposed that $\mathrm{SO}_{2}$ adducts of $\left[\mathrm{Ni}\left(\mathrm{PBu}_{3}\right)\left(\eta^{5}-\mathrm{C}_{5}\right.\right.$ $\left.\left.\mathrm{H}_{5}\right)\left(\mathrm{SC}_{6} \mathrm{H}_{4} \mathrm{X}-4\right)\right]$ have the $\mathrm{SO}_{2}$ bonded to the sulfur of the thiolate ligand [16]. Since the value of $\sigma_{p}$ is a measure of the electron-withdrawing ability of the substituent in the paraposition of the benzene ring to which the sulfur donor atom is attached [24], the increased formal potential of the $\mathrm{SO}_{2}$ adducts confirms the behavior of $\mathrm{SO}_{2}$ as a Lewis acid that binds to the thiolate sulfur by accepting electrons. This bonding mode in turn reduces electron density at the metal center, hence the increase in formal oxidation potentials of $\mathrm{SO}_{2}$ adducts.

\subsection{Type 2 Electrochemical $\mathrm{SO}_{2}$ Sensors: $\left[\mathrm{Ni}\left(\mathrm{PBu}_{3}\right)\right.$ $\left.\left(\eta^{5}-\mathrm{C}_{5} \mathrm{H}_{5}\right)\left(\mathrm{SC}_{6} \mathrm{H}_{4} \mathbf{N C}(\mathrm{H}) \mathrm{C}_{6} \mathrm{H}_{4} \mathrm{X}-4\right)\right]$}

Type 2 complexes represent a modification of Type 1 compounds in which the substituent on the thiolate ligand has an imine functionality. Typical voltammograms of the Type 2 compounds are shown in Figure 4 for $\left[\mathrm{Ni}\left(\mathrm{PBu}_{3}\right)\right.$ $\left.\left(\eta^{5}-\mathrm{C}_{5} \mathrm{H}_{5}\right) \mathrm{SC}_{6} \mathrm{H}_{4} \mathrm{NC}(\mathrm{H}) \mathrm{C}_{6} \mathrm{H}_{4} \mathrm{CH}_{3}-4\right]$ and its $\mathrm{SO}_{2}$ adduct. Electrochemical data for $\mathrm{F}, \mathrm{OCH}_{3}$ and $\mathrm{CH}_{3}$ substituents of the $\mathrm{SO}_{2}$-free complex are contained in Table 1. The compounds exhibit the quasi reversible electrochemistry $\left(I_{\mathrm{p}, \mathrm{a}} / I_{\mathrm{p}, \mathrm{c}}\right.$ values are approximately unity and the $\Delta E_{\mathrm{p}}$ values for $\mathrm{X}=\mathrm{F}$ and $\mathrm{OCH}_{3}$ are within $59 \pm 6 \mathrm{mV}$ ) of a diffusion controlled system, as has been reported for related compounds [19]. The formal potential values of the complexes are 345,345 and $351 \mathrm{mV} / \mathrm{Ag}-\mathrm{AgCl}$ for the $\mathrm{F}, \mathrm{OCH}_{3}$ and $\mathrm{CH}_{3}$ substituents, respectively. Unlike Type 1 compounds, the

Table 1. Electrochemical data for cyclopentadienylnickel thiolate complexes screened for $\mathrm{SO}_{2}$ adduct formation.

\begin{tabular}{|c|c|c|c|c|c|}
\hline Sensor material & $E_{\mathrm{p}, \mathrm{a}}(\mathrm{mV})$ & $E_{\mathrm{p}, \mathrm{c}}(\mathrm{mV})$ & $\Delta E_{\mathrm{p}}(\mathrm{mV})$ & $E^{\circ \prime}(\mathrm{mV})$ & $I_{\mathrm{p}, \mathrm{a}} / I_{\mathrm{p}, \mathrm{c}}$ \\
\hline \multicolumn{6}{|l|}{ Type 1 Complexes and $\mathrm{SO}_{2}$ Adducts } \\
\hline$\left[\mathrm{Ni}\left(\mathrm{PBu}_{3}\right)\left(\eta^{5}-\mathrm{C}_{5} \mathrm{H}_{5}\right)\left(\mathrm{SC}_{6} \mathrm{H}_{4} \mathrm{NH}_{2}-4\right)\right]$ & 283 & 223 & 59 & 256 & 1.50 \\
\hline$\left[\mathrm{Ni}\left(\mathrm{PBu}_{3}\right)\left(\eta^{5}-\mathrm{C}_{5} \mathrm{H}_{5}\right)\left(\mathrm{SC}_{6} \mathrm{H}_{4} \mathrm{~F}-4\right)\right]$ & 359 & 302 & 57 & 331 & 1.07 \\
\hline$\left[\mathrm{Ni}\left(\mathrm{PBu}_{3}\right)\left(\eta^{5}-\mathrm{C}_{5} \mathrm{H}_{5}\right)\left(\mathrm{SC}_{6} \mathrm{H}_{4} \mathrm{~F}-4\right)\right] \mathrm{SO}_{2}$ & 422 & 359 & 63 & 391 & 1.22 \\
\hline$\left[\mathrm{Ni}\left(\mathrm{PBu}_{3}\right)\left(\eta^{5}-\mathrm{C}_{5} \mathrm{H}_{5}\right)\left(\mathrm{SC}_{6} \mathrm{H}_{4} \mathrm{Br}-4\right)\right]$ & 434 & 333 & 101 & 384 & 1.08 \\
\hline$\left[\mathrm{Ni}\left(\mathrm{PBu}_{3}\right)\left(\eta^{5}-\mathrm{C}_{5} \mathrm{H}_{5}\right)\left(\mathrm{SC}_{6} \mathrm{H}_{4} \mathrm{Cl}-4\right)\right]$ & 488 & 374 & 114 & 431 & 0.91 \\
\hline$\left[\mathrm{Ni}\left(\mathrm{PBu}_{3}\right)\left(\eta^{5}-\mathrm{C}_{5} \mathrm{H}_{5}\right)\left(\mathrm{SC}_{6} \mathrm{H}_{4} \mathrm{Cl}-4\right)\right] \mathrm{SO}_{2}$ & 471 & 352 & 119 & 412 & 1.08 \\
\hline \multicolumn{6}{|l|}{ Type 2 Complexes } \\
\hline$\left[\mathrm{Ni}\left(\mathrm{PBu}_{3}\right)\left(\eta^{5}-\mathrm{C}_{5} \mathrm{H}_{5}\right)\left(\mathrm{SC}_{6} \mathrm{H}_{4} \mathrm{NC}(\mathrm{H}) \mathrm{C}_{6} \mathrm{H}_{4} \mathrm{~F}-4\right)\right]$ & 376 & 313 & 64 & 345 & 1.10 \\
\hline$\left[\mathrm{Ni}\left(\mathrm{PBu}_{3}\right)\left(\eta^{5}-\mathrm{C}_{5} \mathrm{H}_{5}\right)\left(\mathrm{SC}_{6} \mathrm{H}_{4} \mathrm{NC}(\mathrm{H}) \mathrm{C}_{6} \mathrm{H}_{4} \mathrm{OCH}_{3}-4\right]\right.$ & 354 & 297 & 57 & 326 & 1.04 \\
\hline$\left[\mathrm{Ni}\left(\mathrm{PBu}_{3}\right)\left(\eta^{5}-\mathrm{C}_{5} \mathrm{H}_{5}\right)\left(\mathrm{SC}_{6} \mathrm{H}_{4} \mathrm{NC}(\mathrm{H}) \mathrm{C}_{6} \mathrm{H}_{4} \mathrm{CH}_{3}-4\right]\right.$ & 369 & 332 & 37 & 351 & 1.01 \\
\hline
\end{tabular}




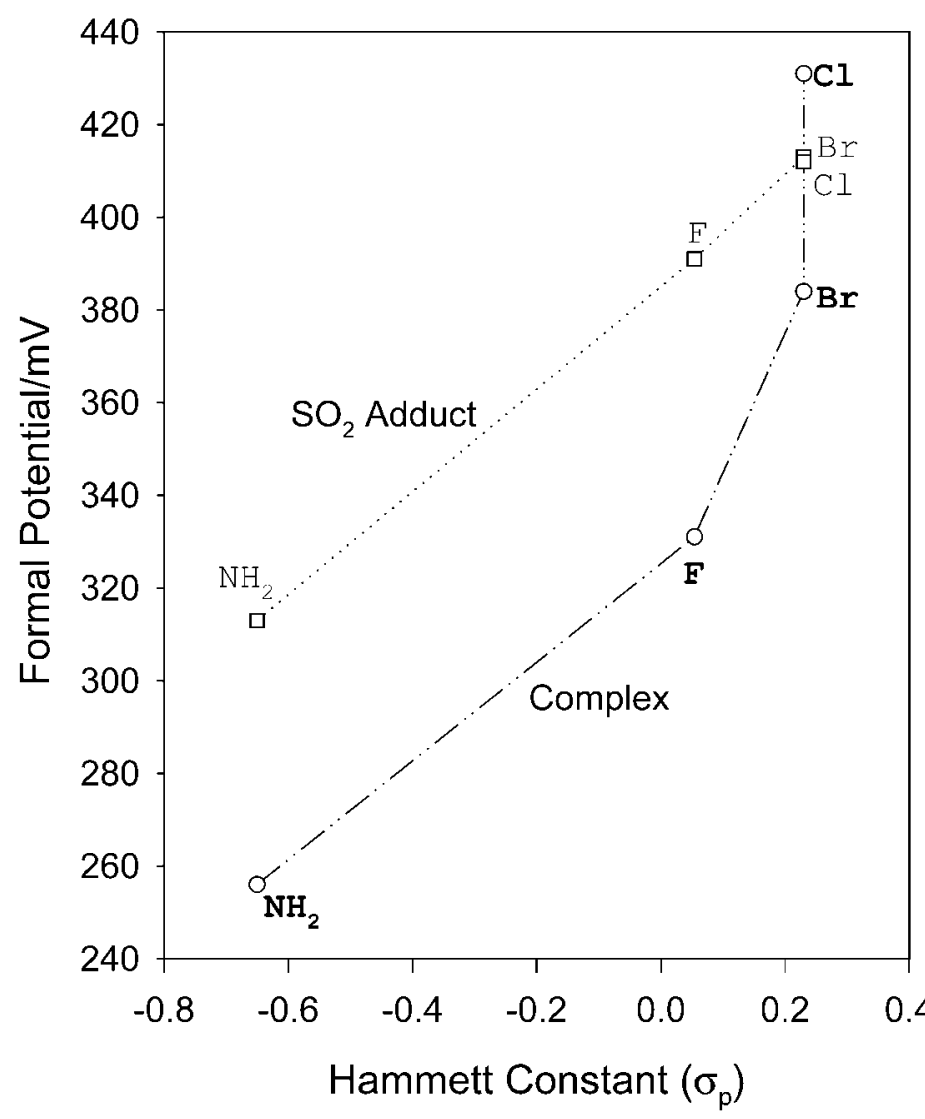

Fig. 3. The dependence of the formal potentials of $\left[\mathrm{Ni}\left(\mathrm{PBu}_{3}\right)\left(\eta^{5}-\right.\right.$ $\left.\left.\mathrm{C}_{5} \mathrm{H}_{5}\right)\left(\mathrm{SC}_{6} \mathrm{H}_{4} \mathrm{X}-4\right)\right]\left(\mathrm{X}=\mathrm{NH}_{2}, \mathrm{~F}, \mathrm{Cl}, \mathrm{Br}\right)$ complexes and $\mathrm{SO}_{2}$ adducts on the Hammett constants of the para-substituents on the thiolate ligand.

electrochemistry of the $\mathrm{SO}_{2}$ adducts depicts the coupling of a chemical reaction to electron transfer process. The CV's of $\left[\mathrm{Ni}\left(\mathrm{PBu}_{3}\right)\left(\eta^{5}-\mathrm{C}_{5} \mathrm{H}_{5}\right)\left(\mathrm{SC}_{6} \mathrm{H}_{4} \mathrm{NC}(\mathrm{H}) \mathrm{C}_{6} \mathrm{H}_{4} \mathrm{CH}_{3}-4\right)\right]$ before and after addition of $\mathrm{SO}_{2}$ confirmed that the $\mathrm{SO}_{2}$ products do not form stable $\mathrm{SO}_{2}$ adducts. Time dependent ${ }^{1} \mathrm{H}$ NMR experiments showed that the cyclopentadienyl singlet, originally at $5.27 \mathrm{ppm}$, shifted as expected to $5.53 \mathrm{ppm} 20 \mathrm{~min}$ after bubbling $\mathrm{SO}_{2}$. Subsequently, the peak at $5.53 \mathrm{ppm}$ was replaced by a new aldehyde peak at $9.99 \mathrm{ppm}$ indicative of the decomposition of the $\mathrm{SO}_{2}$ adduct. Type 2 series of compounds were therefore found to be unsuitable as electrochemical (potentiometric) $\mathrm{SO}_{2}$ sensor materials that would be based on well-defined electrochemistry of both the complexes and their $\mathrm{SO}_{2}$ adducts. However, this class of compounds could still be useful as amperometric $\mathrm{SO}_{2}$ sensor materials.

\subsection{Quantifying $\mathrm{SO}_{2}$ Uptake by Nickel Thiolate Complexes}

Type 1 complexes were used in the quantitative determination of $\mathrm{SO}_{2}$. Experiments were performed by reacting $2 \mathrm{mM}$ cyclopentadienylnickelthiolate (in argon degassed $\mathrm{CH}_{2} \mathrm{Cl}_{2}$ solvent medium containing $\left.0.1 \mathrm{M}\left[n-\mathrm{Bu}_{4} \mathrm{~N}\right]\left[\mathrm{BF}_{4}\right]\right)$

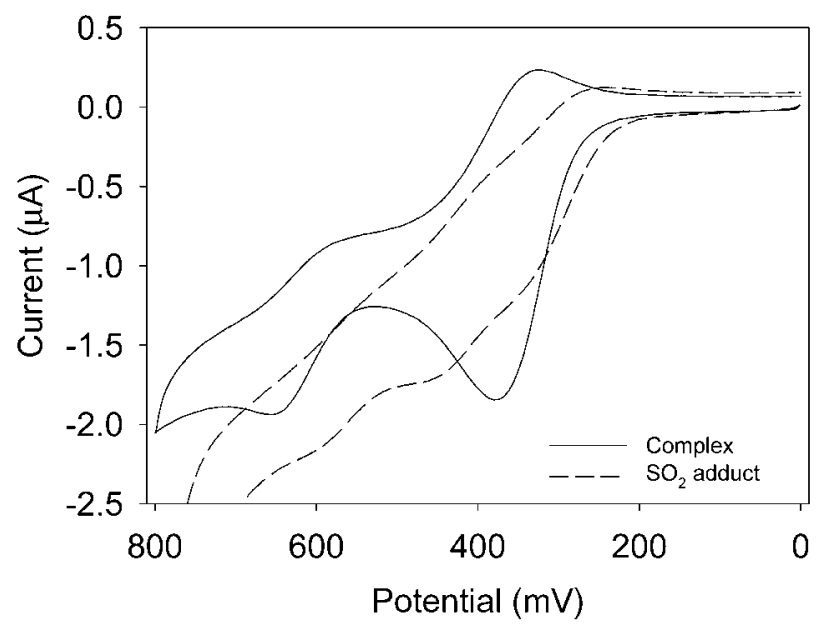

Fig. 4. Cyclic voltammograms for the complex $\left[\mathrm{Ni}\left(\mathrm{PBu}_{3}\right)\left(\eta^{5}-\right.\right.$ $\left.\mathrm{C}_{5} \mathrm{H}_{5}\right)\left(\mathrm{SC}_{6} \mathrm{H}_{4} \mathrm{NC}(\mathrm{H}) \mathrm{C}_{6} \mathrm{H}_{4} \mathrm{CH}_{3}-4\right]$ before and after bubbling of $\mathrm{SO}_{2}$.

with varying amounts of gaseous $\mathrm{SO}_{2}$, measured with a gas tight syringe. Concentration of $\mathrm{SO}_{2}$ gas was calculated in parts per million (ppm) by assuming ideal gas conditions. The performance of the sensor system depended on the complex used. For example, the $\left[\mathrm{Ni}\left(\mathrm{PBu}_{3}\right)\left(\eta^{5}-\mathrm{C}_{5} \mathrm{H}_{5}\right)\left(\mathrm{SC}_{6} \mathrm{H}_{4}\right.\right.$ $\mathrm{NH}_{2} 4$ ] sensor system gave a linear relationship between electrochemical potential and the amount of $\mathrm{SO}_{2}$ from 700 to $2000 \mathrm{ppm}$ with $\mathrm{r}^{2}$ value of 0.993 . The sensitivity of the complex, calculated as the slope of linear calibration plot, was $0.02 \mathrm{mV} \mathrm{ppm}^{-1}$. An $\mathrm{SO}_{2}$ detection limit of $25 \mathrm{ppm}$ was estimated for the nickel thiolate sensor system from the signal to noise ratio. On the other hand the $\left[\mathrm{Ni}\left(\mathrm{PBu}_{3}\right)\left(\eta^{5}-\mathrm{C}_{5}\right.\right.$ $\left.\left.\mathrm{H}_{5}\right)\left(\mathrm{SC}_{6} \mathrm{H}_{4} \mathrm{~F}-4\right)\right]$ sensor system had a low saturation point resulting in a short linear range $(0-20 \mathrm{ppm})$ with $\mathrm{r}^{2}$ values of 0.989 . The fluoro complex exhibited greater sensitivity than its amino analogue with a slope of $0.88 \mathrm{mV} \mathrm{ppm}^{-1}$. A detection limit of $0.56 \mathrm{ppm}$ was calculated for the [Ni $\left.\left(\mathrm{PBu}_{3}\right)\left(\eta^{5}-\mathrm{C}_{5} \mathrm{H}_{5}\right)\left(\mathrm{SC}_{6} \mathrm{H}_{4} \mathrm{~F}-4\right)\right]$ sensor system.

\section{Conclusions}

Both the $\mathrm{SO}_{2}$-free and $\mathrm{SO}_{2}$ adducts of the Type 1 series of cyclopentadienylnickel thiolate complexes, $\left[\mathrm{Ni}\left(\mathrm{PBu}_{3}\right)\left(\eta^{5}-\right.\right.$ $\left.\left.\mathrm{C}_{5} \mathrm{H}_{5}\right)\left(\mathrm{SC}_{6} \mathrm{H}_{4} \mathrm{X}-4\right)\right]$, exhibited stable reversible electrochemistry in $\mathrm{CH}_{2} \mathrm{CH}_{2}$ used as organic phase. However, a shift in formal potential upon the formation of $\mathrm{SO}_{2}$ adduct showed that the compounds were suitable for application as organic phase potentiometric $\mathrm{SO}_{2}$ sensor materials. The linear range for free $\mathrm{SO}_{2}$ determination with the cyclopentadienylnickelthiolate sensor system in organic phase range from $0-20$ ppm to 700-2000 ppm, for the flouro and amine derivatives, respectively. A linear range value of $2-75 \mathrm{ppm}$ (free $\mathrm{SO}_{2}$ ) been reported for spectrophotometric method in $\mathrm{HCl}$ solution [25]. What this means is that the cyclopentadienylnickelthiolate complexes can be tailored to exhibit high or low capacities for $\mathrm{SO}_{2}$ depending on the nature of the para substituent of the thiolate benzene ring. Also the detection 
limits of the organic phase $\mathrm{SO}_{2}$ sensor system can be as low as $0.56 \mathrm{ppm}$ for the fluro or as high as $25 \mathrm{ppm}$ for the amino substituents. The detection limit of the Type 1 fluoro substituted cyclopentadienylnickelthiolate complex compares favorably with the value of $1.0 \mathrm{ppm}$ for free $\mathrm{SO}_{2}$ determined spectrophotmetrically [25]. Within limits of experimental error, $\mathrm{CO}_{2}, \mathrm{~N}_{2}$ and $\mathrm{O}_{2}$ do not interfere with the detection of $\mathrm{SO}_{2}$ with the sensor system. The effect of nitrogen oxides on the sensor was not covered in this study.

\section{Acknowledgement}

Initial support of this work by the International Foundation for Science (IFS), Sweden to JD is gratefully acknowledged.

\section{References}

[1] L. Ferrari, J. Salisbury, Australian National Environmental Health Forum Monographs, Air Series No. 4, 1999.

[2] H. Okabe, F. F. Schwarz, Anal. Chem. 1974, 28, 1024.

[3] Y. Hisamatsu, L. Ping, P. K. Dasgupta, JAPCA 1989, 39, 975.

[4] D. Krochmal, A. Kalina, Atoms. Environ. 1997, 31, 3473.

[5] I. Gracs, R. Ferraoli, Anal. Chim. Acta 1992, 269, 177.

[6] L. M. Reisinger, K. J. Olszyna, T. L. Hetrick, JAPCA 1989, 39, 981.

[7] P. K. Dasgupta, S. Kar, Anal. Chem. 1995, 69, 3853.
[8] G. Shi, M. Luo, J. Xue, Y. Xian, L. Jin, J.-Y. Jin, Talanta 2001, $55,241$.

[9] P. W. T. Lu, R. L. Ammon, J. Electrochem. Soc. 1980, 127, 2610.

[10] T. Hunger, F. Lapicque, Electrochim. Acta 1991, 36, 1073.

[11] F. Magno, G. A. Mazzozhin, G. Bontempelli, J. Electroanal Chem. Interfacial Electrochem. 1994, 57, 89.

[12] P. G. Eller, G. J. Kubas, J. Am. Chem. Soc. 1977, 99, 4346.

[13] W. A. Schenk, E. Dombrowksi, I. Reuther, T. Stur, Z. Naturforsch 1992, 47b, 1823.

[14] A. Shaver, P.-Y. Plouffer, Inorg. Chem. 1992, 31, 1823.

[15] M. Y. Darensbourg, T. Tuntulani, J. H. Reibenspies, Inorg. Chem. 1994, 33, 611.

[16] J. Darkwa, R. M. Moutloali, T. Nyokong, J. Organomet. Chem. 1998 564, 37.

[17] I. Kovacs, C. Pearson, A. Shaver, J. Organomet. Chem. 2001, $596,193$.

[18] M. J. Moloto, S. M. Nelana, R. M. Moutloali, JI. A. Guzei, J. Darkwa, J. Organomet. Chem. 2004, 689, 387.

[19] F. A. Nevondo, A. M. Crouch, J. Darkwa, J. Chem. Soc. Dalton. Trans. 2000, 43.

[20] R. M. Moutloali, J. Basca, J. Darkwa, J. Organomet. Chem. 2001, 629, 171.

[21] W. K. Schropp, J. Inorg. Nucl. Chem. 1962, 24, 1688.

[22] A. Morrin, R. M. Moutloali, M. R. Smyth, A. Killiard, J. Darkwa, E. I. Iwuoha, Talanta 2004, 64, 30.

[23] N. Tanaka, R. Tamamushi, Electrochim. Acta 1964, 9, 963.

[24] C. Hansch, A. Leo, R. W. Taft, Chem. Rev. 1991, 91, 165.

[25] M. A. Segundo, A. O. S. S. Rangel, A. Cladera, V. Cerdà, Analyst 2000, 125, 1501. 